Saudi Journal of Oral and Dental Research

Abbreviated Key Title: Saudi J Oral Dent Res

ISSN 2518-1300 (Print) |ISSN 2518-1297 (Online)

Scholars Middle East Publishers, Dubai, United Arab Emirates

Journal homepage: https://saudijournals.com

Original Research Article

\title{
Is Varenicline More Effective in Long Term Abstinence from Smoking than Nicotine Replacement Therapy (NRT)? A Review
}

\author{
Amit Kumar ${ }^{*}$, Manjunath BC ${ }^{2}$, Adarsh Kumar ${ }^{3}$, Vipul Yadav ${ }^{4}$, Bhavna Sabbarwal ${ }^{5}$, Mansi Mendiratta ${ }^{6}$, Madhavi Wig $^{7}$ \\ ${ }^{1,6,7}$ Postgraduate Student, Department of Public Health Dentistry, Postgraduate Institute of Dental Sciences, Rohtak \\ ${ }^{2}$ Senior Professor and Head, Department of Public Health Dentistry, Postgraduate Institute of Dental Sciences, Rohtak \\ ${ }^{3}$ Professor, Department of Public Health Dentistry, Postgraduate Institute of Dental Sciences, Rohtak \\ ${ }^{4,5}$ Assistant Professor, Department of Public Health Dentistry, Postgraduate Institute of Dental Sciences, Rohtak
}

\author{
DOI: $10.36348 /$ sjodr.2021.v06i04.003 \\ | Received: 24.02.2021 | Accepted: 13.04.2021 | Published: 18.04.2021
}

*Corresponding author: Dr. Amit Kumar

\section{Abstract}

Background: Long term abstinence from smoking is the objective of tobacco cessation therapy. Varenicline, FDA approved a novel beta 4 alpha 2 nAChR partial agonist may offer more benefits. Objectives: To assess the effectiveness and evidence of varenicline over nicotine replacement therapy in extended term abstinence to smoking. Search strategy: A systemic literature survey was carried out identify in electronic database such as PubMed, MEDLINE; Database of Reviews of Effects (DARE); in English language using MeSH terms 'Varenicline' 'Nicotine Replacement Therapy' 'Abstinence' of last 10 years from 2008 to 2020. Selection criteria: We included randomized controlled trials which compared Varenicline when compared with NRT. Results: Initially 182 articles were filtered out, selection of 7 articles by independent reviewer were done. Data from each study were extracted by one reviewer and independently checked for accuracy by a second reviewer. At two years, $28.8 \%$ of participants who were prescribed varenicline and 24.3 percent of those who were prescribed NRT quit; the adjusted odds ratio was 1.26 [95 percent confidence interval (CI): 1.23 to1.29], P 0.0001. At 24 weeks, the RR for varenicline versus NRT for abstinence was 1.25. (95 percent CI 1.14 to 1.37; 8 trials, 6264 people; moderate-quality evidence). Conclusions: An 8-week course of varenicline tends to result in a higher rate of abstinence for up to three years than a similar course of NRT in clinical practice.

Keywords: Varenicline; smoking cessation; NRT (Nicotine Replacement Therapy); Abstinence.

Copyright $\odot 2021$ The Author(s): This is an open-access article distributed under the terms of the Creative Commons Attribution 4.0 International License (CC BY-NC 4.0) which permits unrestricted use, distribution, and reproduction in any medium for non-commercial use provided the original author and source are credited.

\section{INTRODUCTION}

Smoking cessation greatly reduces the risk of tobacco-related morbidity and mortality at all ages 1], including older smokers who have relatively poor health conditions and higher nicotine addiction levels $[2,3]$. Smokers aged 65 and up can benefit up to 3.7 years in life expectancy after quitting. Nicotine replacement therapy (NRT) and varenicline, according to the US Preventive Services Task Force, are successful smoking cessation aids [4]. When compared to a placebo or non-NRT control group, NRT helps smokers quit smoking with a 53 percent-68 percent higher chance of quitting [4-6]. In two head-to-head clinical trials (the EAGLES review and an open-label trial in the United States), as well as in clinical settings, varenicline was found to be more successful than NRT in achieving abstinence [1, 6-8].
Tobacco reduction treatment aims for longterm abstinence from smoking. Varenicline, FDA approved in 2006 a novel alpha 4 beta 2 nAChR partial agonist may offer more benefits. There is little evidence that varenicline and nicotine replacement therapy (NRT) are beneficial for long-term smoking cessation. Nicotine, which is found in tobacco products, is now recognised as being as addictive as heroin or cocaine [9].

The rates of smoking cessation tend to vary by age. Older smokers have a better chance of quitting successfully than younger smokers [10], likely because they are more motivated, have a higher participation rate, and have more health issues $[9,10]$. According to a meta-analysis of clinical trials, smokers aged 50 and up have a 3-fold greater risk of maintaining abstinence with pharmacological intervention [10]. However, the efficacy of varenicline versus NRT in older smokers has 
Amit Kumar et al; Saudi J Oral Dent Res, Apr, 2021; 6(4): 151-156

not been studied. The efficacy of varenicline in comparison to NRT could be influenced by sex and nicotine dependency level, according to new evidence $[9,10]$.

Nicotine causes the brain to release dopamine and other neurotransmitters, reinforcing the smoker's addiction to nicotine. Cardiovascular Disease is the main cause of preventable death, with people having a $70 \%$ risk of dying from coronary heart disease and lung disease. Due to the addictive nature of nicotine, quitting is extremely difficult, with up to $60 \%$ of people relapsing within the first year. Smoking, in addition to its positive reinforcement properties, can become a selfmedicating behaviour with long-term habituation, reducing negative affect and modulating withdrawal symptoms [10]. Smokers that have life-threatening illnesses that could be caused in part by their cigarette use still have a hard time quitting, with as many as $70 \%$ of those who survive a heart attack resuming smoking within a year (40 percent while still in the hospital) and about $50 \%$ of lung cancer patients resuming smoking after surgery [10]. So, this review was undertaken to to assess the effectiveness and evidence of varenicline over nicotine replacement therapy in long term abstinence to smoking.

\section{MATERIAL AND METHODOLOGY}

We included all reviews that included pharmacotherapy (varenicline or NRT) for smoking cessation. These are usually adult smokers, of either gender, and of any nationality and ethnicity. We have included all the data from those reviews which focus on populations of smokers, e.g., adults with mental health problems, smokeless tobacco users [11], or pregnant women [9], as such reviews cover a range of interventions beyond the pharmacotherapies which are the subject of this overview.

However, trials of pharmacological interventions which target specific groups of smokers, settings, intervention delivery and cessation techniques are included within the relevant sections of this overview, classified by the type of intervention.

Search strategy: A systematic literature survey was carried out to identify in electronic database such as PubMed, MEDLINE; Database of Reviews of Effects (DARE); in English language using MeSh terms 'Varenicline' 'Nicotine Replacement Therapy' 'Abstinence' of last 10 years from 2010 to 2020. (Figure-1). Characteristics of all the includes studies were tabulated (Table-1).

Selection criteria: We included randomized controlled trials which compared Varenicline when compared with NRT.

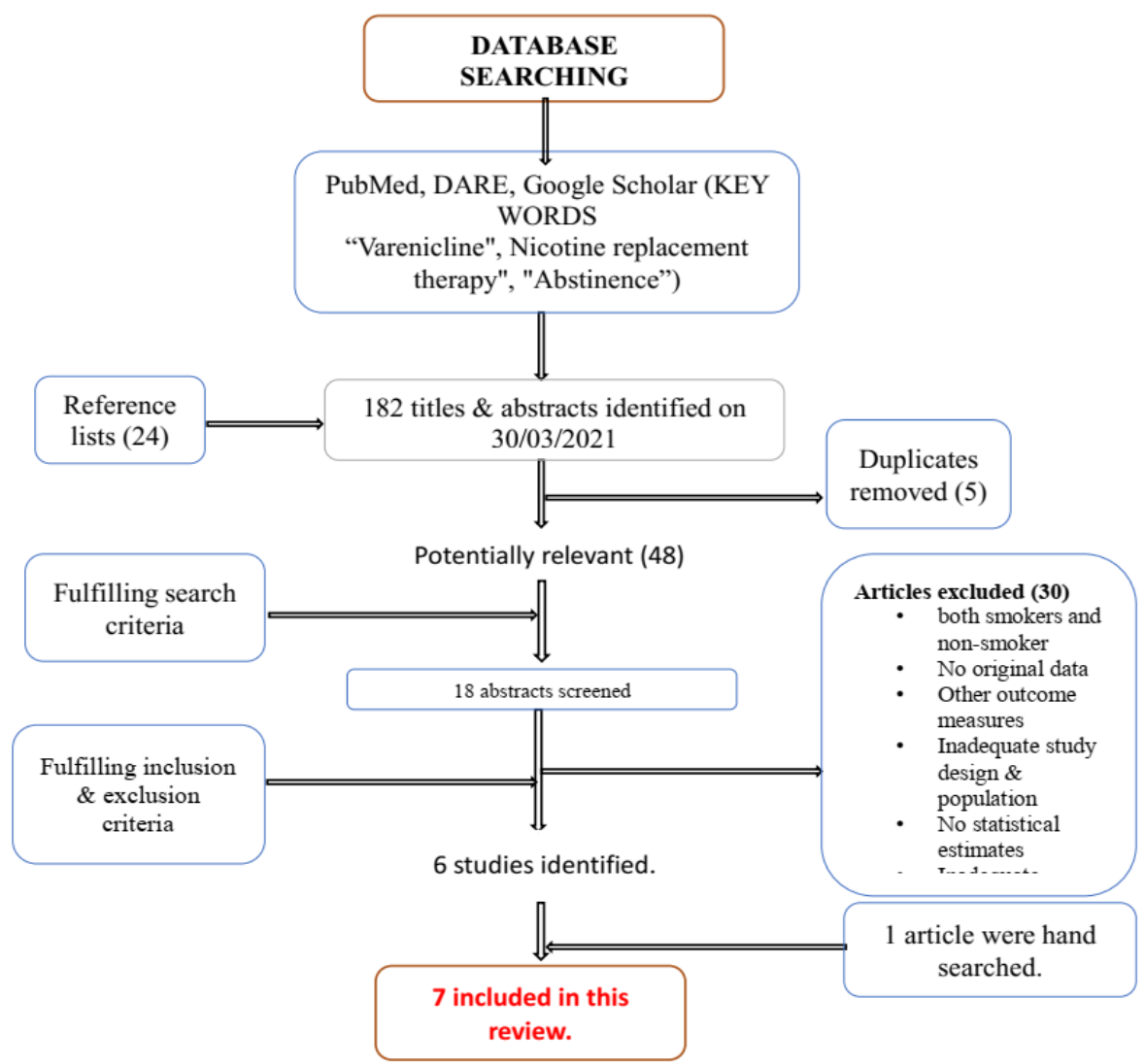

Fig-1: Flowchart depicting the search strategy employed for the review 
Amit Kumar et al; Saudi J Oral Dent Res, Apr, 2021; 6(4): 151-156

\begin{tabular}{|c|c|c|c|}
\hline $\begin{array}{l}\text { AUTHOR } \\
\text { (PUBLICATION } \\
\text { YEAR) }\end{array}$ & $\begin{array}{l}\text { H-J AUBIN (2008) } \\
{[12]}\end{array}$ & T.HITOMI (2010) [13] & K.CAHILL (2013) [14] \\
\hline STUDY DESIGN & $\begin{array}{l}\text { Randomized open label } \\
\text { trial }\end{array}$ & Randomized control Trial & Cochrane network meta anlysis \\
\hline STUDY DURATION & $2005-2006$ & Aug 2018-Nov 2009 & $\begin{array}{l}\text { Last search conducted in } \\
\text { November } 2012\end{array}$ \\
\hline STUDY POPULATION & $\begin{array}{l}\text { Multicentric Belgium, } \\
\text { France, , U.K. ,U.S.A. }\end{array}$ & $\begin{array}{l}\text { Smokers aged between } 27 \text { and } 64 \\
\text { years }\end{array}$ & RCT covering 101,000 smokers \\
\hline SAMPLE SIZE & $\begin{array}{l}746 \\
V=376 ; N=370\end{array}$ & $\begin{array}{l}32 \\
\mathrm{~V}=14 ; \mathrm{N}=14\end{array}$ & 101,000 \\
\hline STUDY LOCATION & $\begin{array}{l}\text { Multicentric smoking } \\
\text { cessation clinic ( } 52 \mathrm{wk} .)\end{array}$ & $\begin{array}{l}\text { Smoking cessation clinic of } \\
\text { Fukuoka University Hospital }\end{array}$ & $\begin{array}{l}\text { Internet based search selecting the } \\
\text { articles }\end{array}$ \\
\hline $\begin{array}{l}\text { METHOD OF } \\
\text { RECRUITMENT }\end{array}$ & $\begin{array}{l}1: 1 \text { randomized } \\
\text { allocation, open label }\end{array}$ & $\begin{array}{l}1: 1 \text { randomization within } 4 \text { weeks } \\
\text { by computer }\end{array}$ & $\begin{array}{l}\text { RCT based on their inclusion and } \\
\text { exclusion criteria, outcome } \\
\text { measuring at least } 6 \text { months from } \\
\text { the start of treatment }\end{array}$ \\
\hline METHODOLOGY & $\begin{array}{l}\text { Data collection and self } \\
\text { reported continuous } \\
\text { abstinence rate }\end{array}$ & $\begin{array}{l}12 \text { week follow up period at } \\
\text { outpatient clinic and abstinence } \\
\text { rates at } 24 \text { weeks were determined } \\
\text { by telephone interview }\end{array}$ & $\begin{array}{l}\text { Effectiveness of smoking cessation } \\
\text { medication comparing the outcome } \\
\text { at up to } 12 \text { months }\end{array}$ \\
\hline $\begin{array}{l}\text { CONFIRMATION/GOLD } \\
\text { STANDARD }\end{array}$ & $\begin{array}{l}\text { CAR; Vern }=55.9 \\
\text { NRT }=43.2 \% \text { at } 4 \mathrm{WK}\end{array}$ & $\begin{array}{l}\text { CAR ; vern }=71.4 \% \\
\text { NRT }=78.6 \%\end{array}$ & Analysis from breath, blood , urine \\
\hline RESULT & $\begin{array}{l}\text { At } 52 \text { wk. CAR; } \\
\text { Vern }=26.1 \\
\text { NRT }=20.3\end{array}$ & $\begin{array}{l}\text { CAR; vern }=64.3 \% \\
\text { NRT }=71.4 \%\end{array}$ & $1.6(95 \%$ CI $(1.3-1.9)$ \\
\hline ODDS RATIO & $1.40(0.99-1.99)$ & $1.02(.96-1.67)$ & $1.6(1.3-1.9)$ \\
\hline
\end{tabular}

\begin{tabular}{|c|c|c|c|}
\hline T. BAKER (2016) & $\begin{array}{l}\text { RM ANTHENELLI(2016) } \\
\text { [1] }\end{array}$ & MV BURKE (2016) [15] & GMJ TAYLOR (2017) [16] \\
\hline $\begin{array}{l}\text { Randomized control trial for } \\
26 \text { week quit rate }\end{array}$ & $\begin{array}{l}\text { Randomized double blind } \\
\text { controlled trial }\end{array}$ & $\begin{array}{l}\text { Review of varenicline for } \\
\text { smoking cessation }\end{array}$ & $\begin{array}{l}\text { Prospective cohort study of electronic } \\
\text { medical records }\end{array}$ \\
\hline May 2012- Nov 2015 & Nov 30,2011-Jan 13,2015 & $\begin{array}{l}\text { January 1966-December } \\
2015\end{array}$ & July 2015-May 2018 \\
\hline $\begin{array}{l}\text { Smokers who were willing to } \\
\text { take part in this study and } \\
\text { willing to quit }\end{array}$ & $\begin{array}{l}\text { Smokers attending at } \\
\text { smoking cessation clinic }\end{array}$ & $\begin{array}{l}\text { Smokers attending the } \\
\text { cessation clinic }\end{array}$ & $\begin{array}{l}\text { Electronic medical record from } 654 \\
\text { general practices in England }\end{array}$ \\
\hline 1086 & 8144 & 10,2300 & 287079 \\
\hline $\begin{array}{l}\text { Smokers recruited in } \\
\text { Wisconsin, and Milwaukee }\end{array}$ & 140 centers in 16 countries & $\begin{array}{l}\text { RCTs adhering to the } \\
\text { inclusion and exclusion } \\
\text { criteria }\end{array}$ & United kingdom \\
\hline $\begin{array}{l}\text { By contacting participants in } \\
\text { ongoing longitudinal study of } \\
\text { smokers. } \\
\text { Via media and community } \\
\text { outreach }\end{array}$ & $\begin{array}{l}\text { Smokers who were willing } \\
\text { to quit along with brief } \\
\text { counselling session }\end{array}$ & $\begin{array}{l}\text { Smokers attending to the } \\
\text { smoking cessation clinic }\end{array}$ & $\begin{array}{l}\text { Smokers attending the general } \\
\text { practitioners for smoking cessation }\end{array}$ \\
\hline $\begin{array}{l}\text { Three group randomized } \\
\text { intention -to-treat clinical } \\
\text { trial }\end{array}$ & $\begin{array}{l}\text { RCT with patients on } \\
\text { varenicline on psychiatric } \\
\text { and non-psychiatric patients }\end{array}$ & $\begin{array}{l}\text { Randomized control trials } \\
\text { smokers attending the } \\
\text { clinic }\end{array}$ & $\begin{array}{l}\text { CPRD to conduct a cohort study of } \\
\text { all patients prescribed varenicline or } \\
\text { nicotine replacement products } \\
\text { followed for } 24 \text { months }\end{array}$ \\
\hline Carbon monoxide confirmed & Biochemically confirmed & $\begin{array}{l}\text { Carbon monoxide } \\
\text { confirmation }\end{array}$ & Biochemically confirmed \\
\hline $\begin{array}{l}\text { Varenicline has similar } \\
\text { effects as NRT on smoking } \\
\text { abstinence at } 24 \text { weeks }\end{array}$ & $\begin{array}{l}\text { CAR at } 24 \text { weeks was } \\
\text { greater for varenicline than } \\
\text { NRT }\end{array}$ & $\begin{array}{l}\text { CAT at } 8 \text { wk was slightly } \\
\text { greater for varenicline } \\
\text { than NRT }\end{array}$ & $\begin{array}{l}\text { Patients prescribed varenicline were } \\
\text { more likely to be abstinence up to } 4 \\
\text { years after first prescription than } \\
\text { NRT }\end{array}$ \\
\hline $1.3(0.9-1.9)$ & $1.5(1.3-1.8)$ & $1.1(1.02-1.78)$ & $1.26(1.23-1.29)$ \\
\hline
\end{tabular}

\section{RESULTS}

Initially 182 articles were filtered out, selection of 7 articles by independent reviewer were done. Data from each study were extracted by one reviewer and independently checked for accuracy by a second reviewer. Findings revealed that at 2 years, $28.8 \%$ of participants prescribed varenicline and $24.3 \%$ of those prescribed NRT quit; adjusted odds ratio was 1.26 [95\% confidence interval (CI): 1.23 to 1.29 ], $\mathrm{P}<$ 0.0001.(Table 2) The RR for varenicline versus NRT 
for abstinence at 24 weeks was 1.25 (95\% CI 1.14 to 1.37; 8 trials, 6264 people; moderate-quality evidence). Four trials which tested the use of varenicline beyond the 12 weeks of standard regimen found the drug to be well-tolerated during long-term use. Point prevalence of quit rates at 3,6 and 9-months and 1,2 and 4-years after exposure is represented as graph (Table-3).

Table-2: Odds-ratios and $95 \%$ confidence intervals for the association between prescription of varenicline versus NRT and smoking cessation

Odds-ratios and 95\% confidence intervals for the association between prescription of varenicline versus NRT and smoking cessation at 3,6 and 9-months and 1,2 and 4-years after exposure.

\begin{tabular}{|l|l|l|l|l|l|}
\hline Odds-ratio (95\% confidence interval) \\
\hline 3-months & 6-months & 9-months & 1-year & 2-years & 4-years \\
\hline 1.42 & 1.45 & 1.40 & 1.35 & 1.26 & 1.19 \\
$(1.37$ to 1.48$)$ & $(1.40$ to 1.51$)$ & $(1.35$ to 1.45$)$ & $(1.30$ to 1.39$)$ & $(1.23$ to 1.30$)$ & (1.16 to 1.22$)$ \\
\hline
\end{tabular}

Table-3: Point prevalence quit rates by instrumental variable condition at 3, 6 and 9-months and 1, 2 and 4-years after exposure

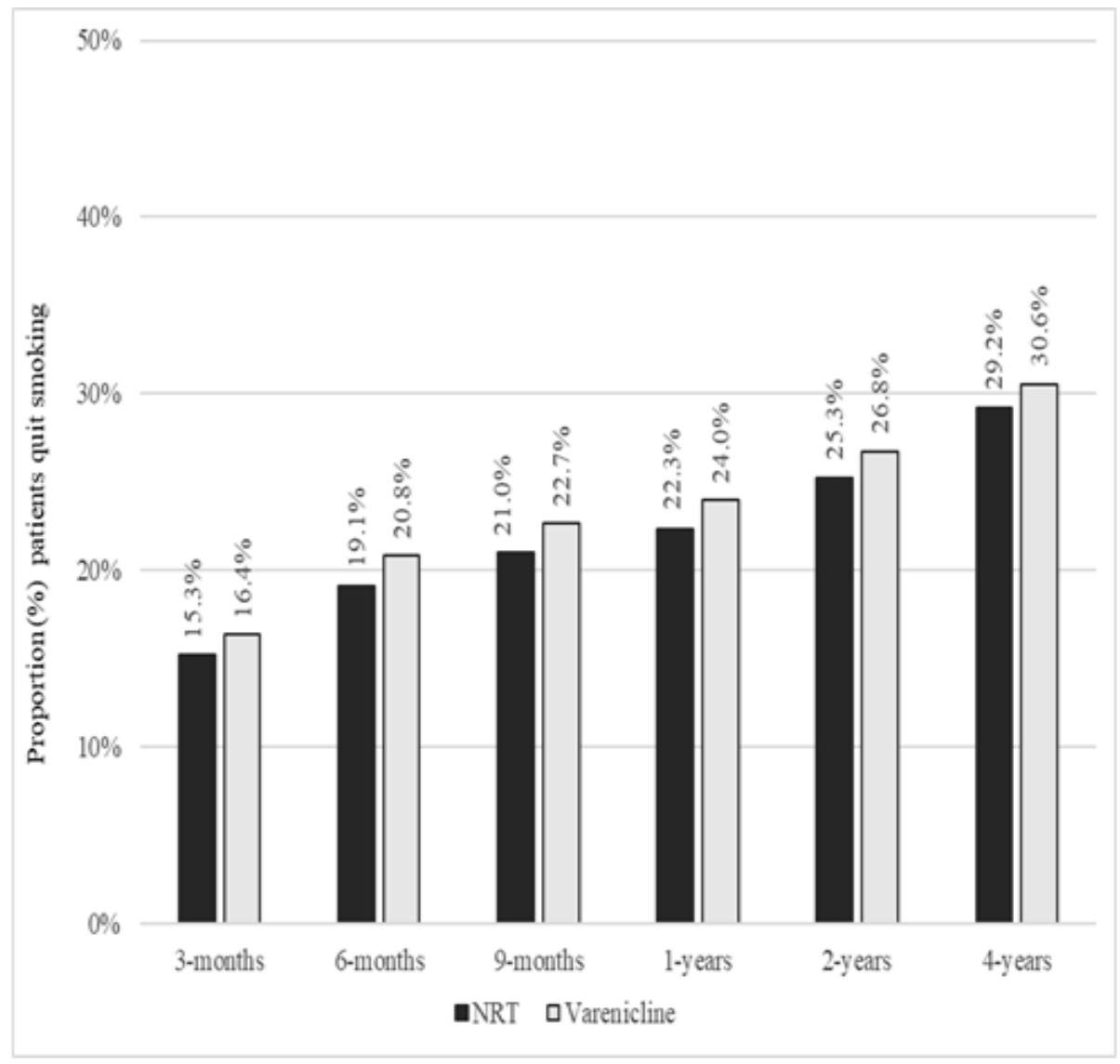

\section{DISCUSSION}

NRT, bupropion, and varenicline are all widely available, both on prescription and, in the case of NRT, over the counter. In the United States and the European Union, they are approved as first-line treatments for use as smoking cessation aids, and they are widely recommended in many national guidelines.

Different treatments use different mechanisms, but the underlying principles are as follows:

i. To alleviate the cravings and withdrawal symptoms that are frequently associated with a quit attempt, and/or ii. Smoking's reward can be reduced by indirectly disrupting dopamine release or desensitising receptors., and/or

iii. To provide some positive reinforcement other than through the use of a cigarette.

It should be noted that the precise mechanisms underlying some therapies are still being researched.

The following are thought to be the major mechanisms of action, either alone or in combination:

i. To block nicotine or blunt nicotine's effects on its receptors or receptors in nicotine-affected 
Amit Kumar et al; Saudi J Oral Dent Res, Apr, 2021; 6(4): 151-156

pharmacological pathways.; these include bupropion, vaccines, mecamylamine, the nicotine receptor partial agonists (varenicline, cytisine, dianicline), selective type 1 cannabinoid receptor antagonists (rimonabant, taranabant), and the opioid antagonists.

ii. To alleviate withdrawal symptoms: these include nicotine replacement therapies, lobeline, varenicline, Nicobrevin; To compensate for the effects of nicotine: these include anxiolytics, antidepressants, clonidine, bupropion; Aversive therapy: silver nitrate; • Sensory replacement: Nicobrevin.

Baker and colleagues [17] discovered that varenicline had the same effects as NRT on smoking abstinence after 26 weeks; the odds ratio was 1.3. (95 percent confidence interval, 0.9 to 1.9). Aubin and colleagues found similar effects between the two medications after a year. [1.4 (95\% confidence interval 0.99 to 1.99$)$ ].

In contrast, Anthenelli and colleagues 2016 [1]concluded that at 24 weeks, those given varenicline had higher rates of abstinence than those given NRT.; odds ratio (and 95\% confidence interval) were 1.5 (1.3 to 1.8$)$.

Cahill and colleagues [18] conducted a network meta-analysis of randomised controlled trials, which revealed that varenicline is the most effective smoking cessation medication for up to 12 months.; odds ratio (and 95\% confidence interval) were 1.6 (1.3 to 1.9$)$.

However, because of differences in treatment delivery and participant characteristics, the efficacy of treatments in clinical trials may differ from their effectiveness in everyday clinical settings. Furthermore, abstinence for 6 to 12 months does not guarantee longer-term abstinence (> 24 months). A systematic review of RCTs discovered that $30 \%$ of participants who reported quitting at the 12-month follow-up relapsed in the following years.

\section{CONCLUSION}

Eight-week course of varenicline appears to yield higher abstinence rate up to 3 years than a similar length course nicotine replacement therapy in routine clinical practice.

\section{Conflict of Interest Statement: Nil}

\section{REFERENCES}

1. Anthenelli, R. M., Benowitz, N. L., West, R., St Aubin, L., McRae, T., Lawrence, D., ... \& Evins, A. E. (2016). Neuropsychiatric safety and efficacy of varenicline, bupropion, and nicotine patch in smokers with and without psychiatric disorders
(EAGLES): a double-blind, randomised, placebocontrolled clinical trial. The Lancet, 387(10037), 2507-2520.

2. Davies, N. M., Taylor, G., Taylor, A. E., Thomas, K. H., Windmeijer, F., Martin, R. M., \& Munafò, M. R. (2015). What are the effects of varenicline compared with nicotine replacement therapy on long-term smoking cessation and clinically important outcomes? Protocol for a prospective cohort study. BMJ open, 5(11), e009665.

3. Kaduri, P., Voci, S., Zawertailo, L., Chaiton, M., McKenzie, K., \& Selby, P. (2015). Real-world effectiveness of varenicline versus nicotine replacement therapy in patients with and without psychiatric disorders. Journal of addiction medicine, 9(3), 169-176.

4. Motooka, Y., Matsui, T., Slaton, R. M., Umetsu, R., Fukuda, A., Naganuma, M., ... \& Nakamura, M. (2018). Adverse events of smoking cessation treatments (nicotine replacement therapy and nonnicotine prescription medication) and electronic cigarettes in the Food and Drug Administration Adverse Event Reporting System, 20042016. SAGE open medicine, 6, 2050312118777953.

5. Green, R., \& Ray, L. A. (2018). Effects of varenicline on subjective craving and relative reinforcing value of cigarettes. Drug and alcohol dependence, 188, 53-59.

6. Watsky, E. J., Gong, J., Williams, K. E., \& Reeves, K. R. (2006). Varenicline, an alpha4beta2 nicotinic acetylcholine receptor partial agonist, vs sustainedrelease bupropion and placebo for smoking cessation: a randomized controlled trial. Jama 296: 4755Gotti C, Zoli M, Clementi F (2006) Brain nicotinic acetylcholine receptors: native subtypes and their relevance. Int $J$ Obes Relat Metab Disord, 28, 27881 Grabowski.

7. Jimenez-Ruiz, C. A., Pascual-Lledó, J. F., CíceroGuerrero, A., Cristóbal-Fernández, M., MayayoUlibarri, M., \& Villar-Laguna, C. (2018). Effectiveness and safety of varenicline and nicotine replacement therapy among mental health patients: A retrospective cohort study. Pulmonology, 24(1), $10-15$.

8. Kotz, D., Brown, J., \& West, R. (2014). Effectiveness of varenicline versus nicotine replacement therapy for smoking cessation with minimal professional support: evidence from an English population study. Psychopharmacology, 231(1), 37-42.

9. Eisenberg, M. J., Filion, K. B., Yavin, D., Bélisle, P., Mottillo, S., Joseph, L., ... \& Pilote, L. (2008). Pharmacotherapies for smoking cessation: a metaanalysis of randomized controlled trials. Cmaj, 179(2), 135-144.

10. Etter, J. F. (2006). Cytisine for smoking cessation: a literature review and a meta-analysis. Archives of internal medicine, 166(15), 1553-1559.

11. Chen, D., \& Wu, L. T. (2015). Smoking cessation interventions for adults aged 50 or older: a 
systematic review and meta-analysis. Drug and alcohol dependence, 154, 14-24.

12. Aubin, H. J., Bobak, A., Britton, J. R., Oncken, C., Billing, C. B., Gong, J., ... \& Reeves, K. R. (2008). Varenicline versus transdermal nicotine patch for smoking cessation: results from a randomised open-label trial. Thorax, 63(8), 717-724.

13. Tsukahara, H., Noda, K., \& Saku, K. (2010). A Randomized Controlled Open Comparative Trial of Varenicline vs Nicotine Patch in Adult SmokersEfficacy, Safety and Withdrawal Symptoms (The VN-SEESAW Study)-. Circulation Journal, 74(4), 771-778.

14. Cahill, K., Stevens, S., Perera, R., \& Lancaster, T. (2013). Pharmacological interventions for smoking cessation: an overview and network metaanalysis. Cochrane database of systematic reviews, (5).

15. Burke, M. V., Hays, J. T., \& Ebbert, J. O. (2016). Varenicline for smoking cessation: a narrative review of efficacy, adverse effects, use in at-risk populations, and adherence. Patient preference and adherence, 10, 435-441.

16. Taylor, G. M., Taylor, A. E., Thomas, K. H., Jones, T., Martin, R. M., Munafo, M. R., ... \& Davies, N. M. (2017). The effectiveness of varenicline versus nicotine replacement therapy on long-term smoking cessation in primary care: a prospective cohort study of electronic medical records. International journal of epidemiology, 46(6), 1948-1957.

17. Baker, T. B., Piper, M. E., Stein, J. H., Smith, S. S., Bolt, D. M., Fraser, D. L., \& Fiore, M. C. (2016). Effects of nicotine patch vs varenicline vs combination nicotine replacement therapy on smoking cessation at 26 weeks: a randomized clinical trial. Jama, 315(4), 371-379.

18. Cahill, K., Stead, L. F., \& Lancaster, T. (2012 Apr). Nicotine receptor partial agonists for smoking cessation. Cochrane Database Syst Rev. (4):CD006103-CD006103. 